\title{
Airway management and oxygenation in obese patients
}

\author{
Caitriona Murphy, MD • David T. Wong, MD
}

Received: 6 March 2013/Accepted: 17 June 2013/Published online: 9 July 2013

(C) Canadian Anesthesiologists' Society 2013

\begin{abstract}
Purpose The purpose of this Continuing Professional Development module is to describe anatomic and physiologic challenges in obese patients, review their effects on oxygenation and airway management, and propose strategies for perioperative management.

Principal findings The combination of excess adipose tissue deposition, increased oxygen consumption, reduced lung volumes, and increased airway resistance in obese patients increases the risk of a difficult airway and rapid oxygen desaturation in the perioperative period. Preoxygenation can be optimized by a head-up or reverse Trendelenburg position, continuous positive airway pressure, and pressure support ventilation. Difficulties in bag and mask ventilation may occur. Laryngeal exposure during direct laryngoscopy is best achieved with the patient in the "ramped" position. Tracheal tube introducers or intubating stylets can assist tracheal intubation when suboptimal laryngeal views are obtained, and video laryngoscopy may help improve the glottic view and success of tracheal intubation. New generation double-lumen supraglottic airway devices provide higher leak pressures and may be safer in obese patients, and they can also provide a conduit for bronchoscopic intubation. In patients with anticipated difficult airways, preparations should be made for awake tracheal intubation. Intraoperatively, ventilatory strategies, such as recruitment maneuvers with positive end-expiratory
\end{abstract}

\section{Murphy, MD}

Department of Anesthesia, Toronto General Hospital, University of Toronto, Toronto, ON, Canada

D. T. Wong, MD ( $\square)$

Department of Anesthesia, Toronto Western Hospital, University of Toronto, 399 Bathurst Street, Toronto, ON M5T 2S8, Canada e-mail: david.wong@uhn.ca pressure, may reduce atelectasis and improve oxygenation. Tracheal extubation in the head-up position and continuous positive airway pressure reduce postoperative hypoxemia. Following a difficult tracheal intubation, extubation over an airway exchange catheter should be considered.

Conclusions Rapid oxygen desaturation may occur in obese patients. Potential difficulties in airway management should be assessed and anticipated, and oxygenation, ventilation, and airway management strategies should be optimized perioperatively.

\section{Objectives of this Continuing Professional Development (CPD) module}

After reading this module, the reader should be able to:

1. Describe the anatomic and respiratory physiologic changes associated with obesity.

2. Recognize the challenges that may be encountered in mask ventilation, supraglottic airway use, tracheal intubation, and the surgical airway of the obese patient.

3. Apply optimization techniques for induction of general anesthesia in obese patients.

4. Plan the method, equipment, and rescue devices required for securing the airway in the obese patient.

5. Anticipate challenges in achieving optimal ventilation of the obese patient under general anesthesia and consider ventilator strategies to minimize complications.

6. Optimize conditions for safe tracheal extubation of the obese patient.

According to Obesity in Canada 2011, approximately one in four Canadian adults (24.3-25.4\%) are obese, and the economic impact of obesity in 2008 was estimated at 
$\$ 4.6$ billion. ${ }^{1}$ The number of obese patients presenting for surgery is increasing. Obesity is defined as a calculated body mass index $(\mathrm{BMI})>30 \mathrm{~kg} \cdot \mathrm{m}^{-2}$, and morbid obesity is defined as a BMI $>40 \mathrm{~kg} \cdot \mathrm{m}^{-2}$. Both total body mass and regional distribution of excess adipose tissue influence the potential for multiple comorbidities associated with this condition. Preoperative assessment therefore plays an important role in identifying such coexisting conditions, optimizing medical management where possible, and planning the perioperative course to minimize morbidity and mortality. ${ }^{2}$ This Continuing Professional Development module focuses on airway management and oxygenation in the obese patient undergoing general anesthesia.

\section{Airway patency and respiratory physiology in obese patients}

The impact of anatomic and physiologic changes on oxygenation and airway management in obese patients is an important consideration in the perioperative setting (Table). Adipose tissue depositions within the pharyngeal structures (predominantly within the lateral pharyngeal walls) protrude into the airway lumen, resulting in narrowing of the lumen, particularly on inspiration. ${ }^{3}$ The combination of a large tongue, excessive upper airway soft tissue, and reduced pharyngeal dilator muscle function during periods of somnolence predisposes the obese patient to obstructive sleep apnea (OSA). ${ }^{4}$ Morbidly obese patients, with or without OSA, have been shown to experience frequent episodes of oxygen desaturation following laparoscopic bariatric surgery, despite supplemental oxygen therapy. ${ }^{5}$

Alterations in respiratory physiology include increased oxygen consumption, higher respiratory rates, reduced lung volumes (most notably functional residual capacity), significantly higher minute ventilation, reduced total respiratory system compliance, and increased airway resistance (Table). ${ }^{6}$ The association of obesity with widening of the alveolararterial $\mathrm{O}_{2}$ gradient appears to be due to ventilation-perfusion mismatch caused by microatelectasis, particularly when the patient is in the supine position. Following induction of general anesthesia in morbidly obese patients, the functional residual capacity decreases by approximately $50 \%$ compared with preanesthetic values. This contrasts with a $20 \%$ decrease in nonobese patients. These physiologic changes predispose the morbidly obese patient to rapid oxygen desaturation with the onset of apnea. $^{7}$

\section{Association between obesity and a difficult airway}

The term "difficult airway" encompasses difficulty encountered with mask ventilation, supraglottic airway,
Table Impact of anatomic and physiologic changes in the obese patient on oxygenation and airway management

\begin{tabular}{ll}
\hline Anatomic changes & Impact \\
\hline Excess adipose tissue deposition within: & \\
- the pharyngeal structures & Airway lumen narrowing \\
- face & Difficult mask ventilation \\
- neck & Difficult surgical airway \\
- thorax & access \\
- abdomen & Reduced chest wall \\
& compliance \\
& Reduced expiratory reserve \\
& volume \\
& Decreased functional \\
& residual capacity \\
& Reduced diaphragmatic \\
& excursion \\
Large tongue & Microatelectasis when \\
Excessive upper airway soft tissue & supine \\
Reduced pharyngeal dilator muscle & Predisposition to \\
function with somnolence & Obstructive Sleep Apnea \\
\hline
\end{tabular}

Respiratory physiologic changes

Ventilation

Increased respiratory rate

Decreased tidal volume

Oxygenation Widened Alveolar-arterial (A-a)

Increased minute ventilation gradient

Increased oxygen consumption

Mild hypoxemia

Lung volumes

Decreased expiratory reserve volume (ERV)

Decreased functional residual capacity (FRC)

Modest reduction in total lung capacity (TLC)

Modest reduction in residual volume (RV)

FRC approaches RV

Closing capacity may exceed FRC within the range of tidal breathing

Compliance $\quad$ Reduced chest wall compliance

Reduced lung compliance

Respiratory function Minimal reduction in $\mathrm{FEV}_{1}$ or FVC

$\mathrm{FEV}_{1} / \mathrm{FVC}$ ratio usually preserved Increased airway resistance (attributed to reduced lung volume, small airway closure, and airway remodelling by proinflammatory adipokines)

$\mathrm{FEV}_{1}=$ forced expiratory volume in one second; $\mathrm{FVC}=$ forced vital capacity 
tracheal intubation, and/or surgical airway. Excess fatty tissue on the face, neck, breasts, thorax, and abdomen may pose substantial airway challenges related to patient positioning, neck extension, bag and mask ventilation, tracheal intubation, oxygenation, and tracheotomy. The United Kingdom Fourth National Audit Project (NAP 4) reviewed major complications of airway management (death, brain damage, emergency surgical airway, unanticipated admission to the intensive care unit, and prolonged stay in the intensive care unit) and reported a fourfold increase in the risk of serious complications in the morbidly obese patient when compared with non-obese patients. ${ }^{8,9}$ Nineteen $(25 \%)$ of the 77 obese patients reviewed in that study suffered brain damage or death. During anesthesia, difficult tracheal intubation was reported in 23 patients, aspiration in eight, tracheal extubation problems in seven, and trauma to the airway in four cases.

\section{Mask ventilation}

Obesity has been identified as an independent predictor of difficult mask ventilation. In a prospective study of 1,502 consecutive patients presenting for surgery under general anesthesia, anesthesiologists encountered difficulty with mask ventilation in 75 instances, but only $17 \%$ of these cases (13 patients) were anticipated. ${ }^{10}$ Using multivariate analysis, BMI $>26 \mathrm{~kg} \cdot \mathrm{m}^{-2}$ was identified as one of five independent predicators of difficult mask ventilation. ${ }^{10} \mathrm{~A}$ review of 22,660 mask ventilation attempts identified BMI $>30 \mathrm{~kg} \cdot \mathrm{m}^{-2}$ to be an independent predictor of difficult mask ventilation and an independent predictor of difficult or impossible mask ventilation and difficult tracheal intubation. ${ }^{11}$ Nevertheless, a further study of over 50,000 anesthetics failed to show obesity as an independent predictor of impossible mask ventilation. ${ }^{12}$ In this study, ${ }^{12}$ radiotherapy to the neck, male sex, presence of a beard, and Mallampati scores 3 or 4 were identified as independent predictors of impossible mask ventilation. In summary, obesity is associated with potential difficult mask ventilation; therefore, in anticipated or unanticipated difficult mask ventilation, supraglottic airways should be readily available at induction of anesthesia.

\section{Supraglottic airway devices (SGAs)}

Supraglottic airway devices are commonly used in both elective and rescue airway management, but how successful or safe are these supraglottic devices in the obese patient? In a study population of over 15,000 patients, obesity was found to be an independent predictor of failed use of a Laryngeal Mask Airway (LMA) Unique $^{\mathrm{TM}}$, requiring device removal and endotracheal intubation. Inadequate ventilation due to leak and airway obstruction was found in $42.4 \%$ and $30 \%$ of airway events, respectively. ${ }^{13}$ Double-lumen SGAs with gastric channels have been shown to provide effective ventilation in morbidly obese patients when used as a bridge before laryngoscope-guided tracheal intubation, and when compared with face-mask ventilation in novice hands, SGAs were associated with significantly easier and superior ventilation scores. ${ }^{14,15}$ Double-lumen SGAs, such as the LMA ProSeal ${ }^{\mathrm{TM}}$ and the LMA Supreme ${ }^{\mathrm{TM}}$, provide higher leak pressures and may be safer in patients with obesity; ${ }^{16}$ however, SGAs do not protect the airway from aspiration. Eight of the 23 cases of aspiration of gastric contents during anesthesia-reported as the primary airway event in NAP 4-occurred in obese patients. ${ }^{8}$ Overall, eight patients died and two patients suffered brain damage as a result of gastric content aspiration. ${ }^{9}$ Obesity is therefore a relative contraindication of SGA use and caution is advised.

\section{Direct laryngoscopy and intubation}

Is direct laryngoscopy or tracheal intubation more difficult in the obese patient? Juvin et al. reported a $15.5 \%$ rate of difficult tracheal intubation in obese patients compared with a $2.2 \%$ rate in lean patients. ${ }^{17}$ While some studies showed an association between obesity and difficult intubation, controversy still exists, and there is insufficient evidence to support increased BMI alone as an independent predictor of difficult laryngoscopy or difficult intubation. ${ }^{17,18}$ In a cohort of 91,332 consecutive patients, a BMI $>35 \mathrm{~kg} \cdot \mathrm{m}^{2}$ was found to be a statistically significant predictor of difficult and failed intubation. ${ }^{19}$ Conversely, Erzi et al. found that BMI was not an independent predictor of direct laryngoscopy view; ${ }^{20}$ however, in this study, the combination of BMI and abnormal upper teeth was a significant predictor of difficult laryngoscopy. ${ }^{20}$ By using ultrasound to quantify anterior neck soft tissue at the level of the vocal cords, Erzi et al. observed that morbidly obese patients in whom difficult laryngoscopy was encountered had more pre-tracheal soft tissue and a greater neck circumference than patients who experienced an uncomplicated laryngoscopy; pre-tracheal soft tissue thickness was [mean (SD)] 28 (2.7) $\mathrm{mm} \mathrm{vs}$ $17.5(1.8) \mathrm{mm}$, respectively $(P<0.001)$ and neck circumference was $50(3.8) \mathrm{cm}$ vs 43.5 (2.2) cm, respectively $(P<0.001){ }^{21}$ Komatsu et al. did not find increased pre-tracheal tissue to be a good predictor of difficult laryngoscopy in obese patients; ${ }^{22}$ however, the patients in this study had a comparatively smaller neck 

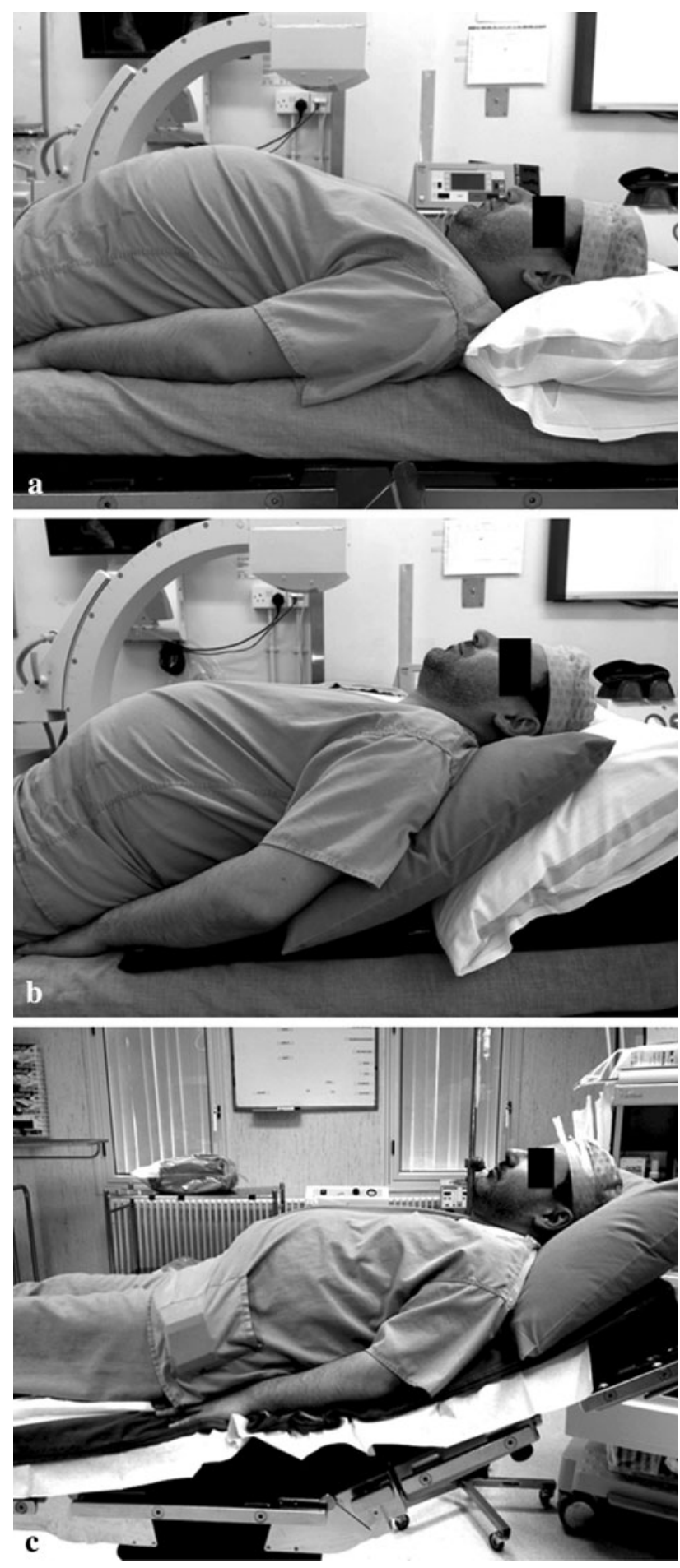

circumference [ 43.5 (4.7) $\mathrm{cm} v s 44.3(5.3) \mathrm{cm} ; P<0.5]$ in the difficult and easy laryngoscopy groups, respectively. Further studies are required to clarify the role of ultrasound and pre-tracheal adipose tissue quantification as a predictor of difficult laryngoscopy.

Direct laryngoscopic view may be affected by patient positioning and can be optimized by aligning the external
4Figure Positioning the patient to improve laryngeal inlet view during direct laryngoscopy. a) Supine position in the "sniff" position, b) horizontal alignment of the sternal notch with the external auditory meatus in the "ramped" position using elevation pillows, and c) "ramped" table position achieved using the beach chair position

Figure Positionnement du patient pour améliorer la visualisation du larynx pendant une laryngoscopie directe. a) Position dorsale en position de 'reniflement', b) alignement horizontal de l'échancrure sternale et du méat auditif externe en position 'inclinée' à l'aide d'oreillers, et c) position 'inclinée' de la table réalisée à l'aide de la position de chaise de plage

auditory meatus with the sternal notch, as discussed later in the review. ${ }^{23}$ Overall lack of agreement on whether tracheal intubation is more difficult in the morbidly obese may be due to particular confounders, including variations in the definitions of difficult intubation (more than three attempts, intubation difficulty scale $>5$ ) and difficult laryngoscopy (Cormack and Lehane grade $\geq 3$ ), patient position, operator experience, and laryngoscopy technique (direct $v s$ video laryngoscopy). There is agreement, however, that a combination of features, such as Mallampati score $\geq 3$ and larger neck circumference, in the obese patient does increase the risk of difficult laryngoscopy and difficult tracheal intubation. ${ }^{24,25}$

\section{Surgical airway}

In a "can't intubate, can't ventilate" scenario, emergency cricothyroidotomy can be particularly challenging in the obese patient because of obscured anatomical landmarks. Aslani et al. investigated the ability of physicians to identify the cricothyroid membrane correctly in obese $(n=15)$ and non-obese $(n=41)$ female patients in whom the cricothyroid membrane had been identified beforehand with ultrasound. The cricothyroid membrane was correctly identified in $1 / 15$ obese patients and 12/41 non-obese patients. ${ }^{26}$ The emerging role of ultrasound in identifying airway anatomy presents the advantage of turning a blind technique into one that is guided $^{27}$ and offering the possibility to identify the cricothyroid membrane accurately in patients with large neck circumference and impalpable landmarks, irrespective of physician experience. $^{28}$

As challenges may be encountered in mask ventilation, supraglottic airway use, tracheal intubation, and cricothyroidotomy in the morbidly obese patient, a cautious approach is advised and awake tracheal intubation should be considered in patients with known or anticipated difficult airways. 


\section{Patient optimization for induction of anesthesia}

Positioning and preoxygenation

Optimal positioning of the obese patient is vital prior to induction of general anesthesia. The $25^{\circ}$ head-up and reverse Trendelenburg positions have been shown to increase the duration of apnea without desaturation compared with the supine position, thus increasing the time for tracheal intubation. ${ }^{29,30}$ In a randomized controlled trial, preoxygenation of morbidly obese patients in the $25^{\circ}$ head-up position led to a $23 \%$ higher oxygen tension than in the supine position [442 (104) $\mathrm{mmHg}$ vs 360 (99) $\mathrm{mmHg}$, respectively; $P=0.012$ ) and a significant increase in the duration of apnea prior to desaturation [201 (55) sec vs 155 (69) sec, respectively; $P=0.023] .{ }^{29}$ The head-elevated laryngoscopy position improves laryngeal exposure during direct laryngoscopy. ${ }^{31}$ In the obese patient population this is achieved by the horizontal alignment of the sternal notch with the external auditory meatus in the "ramped" position. To achieve this visual alignment, the use of multiple folded blankets and commercially available elevation pillows under the upper body, shoulders, and head or the "ramped" table position have been advocated. ${ }^{23}$ The beach chair position has also been shown to facilitate intubation ${ }^{18}$ (Figure).

Induction of general anesthesia is a high-risk period for hypoxemia. Even with preoxygenation, the duration of apnea prior to desaturation can be anticipated to be significantly shorter in the morbidly obese than in patients of normal weight. ${ }^{32}$ Preoxygenation is considered to be sufficient when the end-tidal oxygen fraction is $>90 \% .{ }^{33}$ Tidal volume breathing through a well-sealed face mask for three minutes or four vital capacity breaths are common techniques of preoxygenation. Evidence suggests that obese patients desaturate faster with the latter technique. ${ }^{34}$ Additional techniques for peri-induction oxygenation include supplemental nasopharyngeal oxygen insufflation, semi-recumbent position, continuous positive airway pressure (CPAP), positive end-expiratory pressure (PEEP), and pressure support ventilation applied before induction of general anesthesia in the spontaneous ventilating patient. $^{28-31}$ Baraka et al. compared preoxygenation followed by nasopharyngeal oxygen insufflation (study group) with preoxygenation alone (control group) in morbidly obese patients placed in a $25^{\circ}$ head-up position. ${ }^{35}$ In the study group, 16 of 17 patients maintained oxygen saturation at $100 \%$ during four minutes of apnea. All 17 patients in the control group experienced oxygen desaturation from 100 to $95 \%$ in a mean time of 145 (27) sec. The use of $10 \mathrm{~cm} \mathrm{H}_{2} \mathrm{O}$ continuous positive airway pressure/positive endexpiratory pressure (CPAP/PEEP) throughout the induction period (CPAP when breathing and PEEP after apnea) has been shown to increase the duration of apnea prior to desaturation by $50 \%$ in morbidly obese patients. $^{36,37}$ Noninvasive positive pressure ventilation using pressure support ventilation with PEEP via a face mask has also been shown to enhance preoxygenation, achieving a more rapid increase and higher end-tidal $\mathrm{O}_{2}$ when compared with preoxygenation with spontaneous ventilation. $^{38}$

\section{Choice of intubation techniques}

\section{Direct vs indirect laryngoscopy}

Optimal positioning of the patient will serve to optimize success of tracheal intubation with direct laryngoscopy. The use of a tracheal tube introducer (Eschmann ${ }^{\mathrm{TM}}$ or Frova $^{\mathrm{TM}}$ ) or an intubating malleable stylet as an adjunct to assist intubation should be considered when suboptimal laryngeal inlet views are obtained. ${ }^{39,40}$

Alternatively, indirect laryngoscopy can be performed using video and optical laryngoscopes, thus avoiding the need to align oral and pharyngeal axes. In a study comparing videoassisted with direct laryngoscopy in 318 morbidly obese patients, the Airtraq ${ }^{\mathrm{TM}}$ and LMA CTrach ${ }^{\mathrm{TM}}$ provided an earlier definitive airway and shortest apnea time, respectively, when compared with the conventional Macintosh laryngoscope. $^{41}$ Video-assisted techniques resulted in significantly better percentage of glottis opening (POGO) scores compared with direct laryngoscopy (97\% vs $75 \%$, respectively; $P<0.01$ ). Andersen et al. also found that the Glidescope ${ }^{\circledR}$ video laryngoscope provided better glottic views and lower intubation difficulty scores when compared with the Macintosh laryngoscope in morbidly obese patients. ${ }^{42}$ While an optimal laryngeal inlet view does not necessarily translate into easier intubation, advancement of the endotracheal tube may be assisted using a guiding channel on the device or an introducer. Despite the increasing number of available airway devices, no single video laryngoscope has shown superiority for use in the obese patient; however, video laryngoscopes do provide better laryngeal visualization and should be readily available for airway management.

\section{Intubating adjuncts: use of SGAs}

In the anesthetized patient, fibreoptic intubation may be hampered by loss of upper airway tone and collapsibility of the airway passage. Supraglottic airway devices not only facilitate oxygenation and ventilation of the lungs, but also act as conduits or stents to maintain an open airway and possibly improve visualization of and access to the 
laryngeal inlet in the presence of a soiled and/or bloody field. ${ }^{43}$ Several techniques have been described. An endotracheal tube may be railroaded over a bronchoscope through the SGA and positioned under direct vision prior to removal of the bronchoscope. Alternatively an Aintree Intubating Catheter (Cook Critical Care, Bloomington, IN, USA) may be advanced over the bronchoscope into the trachea through the SGA. The bronchoscope and SGA are sequentially removed leaving the intubating catheter in situ to serve as a "railroading" device for endotracheal tube placement (maximum tube size, $7.0 \mathrm{~mm}$ internal diameter). This technique has been described in both awake and anesthetized patients with difficult airways. ${ }^{44,45}$ When comparing use of an intubating laryngeal mask airway (i.e., LMA-Fastrach ${ }^{\mathrm{TM}}$ ) in both lean and morbidly obese patients, it was shown to be an efficient airway device in both populations, with obese patients requiring significantly fewer airway adjustment maneuvers. ${ }^{46}$

\section{Awake bronchoscopic and video laryngoscopic intubation}

Awake tracheal intubation enables securing the airway in a spontaneously breathing patient before induction of anesthesia and therefore bypassing some of the difficulties that may be encountered under general anesthesia. Awake intubation should therefore be considered for patients with either a documented history or clinical predictors of difficult mask ventilation, laryngoscopy, and surgical cricothyroidotomy. Flexible bronchoscopic intubation requires training and experience and may be challenging in the morbidly obese patient because of the anatomic changes discussed above. Preparation of the patient for awake tracheal intubation includes optimal positioning ("ramped" or reverse Trendelenburg) and preoxygenation, as mentioned above. Tongue protrusion, jaw thrust maneuver, or oral airway adjuncts (e.g., Ovassapian, Berman, and Williams airways) may assist pharyngeal airway access and visualization. The benefit of a more direct passage of the bronchoscope through the nasal route into the pharynx should be weighed against the risk of epistaxis. Local anesthetic topicalization of the airway to blunt airway responses, with or without conscious sedation, will improve patient tolerance. The use of awake video laryngoscopy-assisted tracheal intubation has also been described in the literature as an alternate to flexible bronchoscopic intubation. ${ }^{47}$

\section{Ventilator strategies and intraoperative considerations}

Mechanical ventilation and muscle paralysis in the obese patient under general anesthesia have been shown to impair pulmonary function, lung compliance, and gas exchange as a result of reduced lung volume and atelectasis. ${ }^{48}$ These consequences may be further exacerbated by pneumoperitoneum and patient positioning for surgery (supine, lithotomy, and Trendelenburg position). ${ }^{49}$ Special attention should be paid to ventilatory strategies aimed at minimizing these complications. In a computerized tomography study of morbidly obese patients under general anesthesia, the combination of a recruitment maneuver at $55 \mathrm{~cm} \mathrm{H}_{2} \mathrm{O}$ for ten seconds followed by $10 \mathrm{~cm} \mathrm{H}_{2} \mathrm{O}$ PEEP reduced atelectasis and improved oxygenation more than PEEP or a recruitment maneuver alone. ${ }^{50}$ Obese patients receiving a vital capacity maneuver (VCM) $40 \mathrm{~cm} \mathrm{H}_{2} \mathrm{O}$ for seven to eight seconds followed by PEEP $10 \mathrm{~cm} \mathrm{H}_{2} \mathrm{O}$ were observed to have improved intraoperative and postoperative oxygenation, and their atelectasis scores were lower on chest computerized tomography at two hours postoperatively when compared with obese patients receiving VCM alone. ${ }^{51}$ Almarakbi et al. also observed superior respiratory compliance and $\mathrm{PaO}_{2}$ in obese patients undergoing laparoscopic gastric banding with repeated inspiratory recruitment maneuvres (40 $\mathrm{cm} \mathrm{H}_{2} \mathrm{O}$ for $15 \mathrm{sec}$ repeated every ten minutes) followed by PEEP $\left(10 \mathrm{~cm} \mathrm{H}_{2} \mathrm{O}\right){ }^{52}$ Obese patients may require high peak airway pressures with the application of PEEP $10 \mathrm{~cm} \mathrm{H}_{2} \mathrm{O}$ after recruitment maneuvers. While barotrauma was not reported in these studies, caution should be exercised. In a review of mechanical ventilation in obese patients by Silva et al., the authors recommended stepwise incremental recruitment maneuvers to reduce hemodynamic instability and found no evidence supporting one mode of ventilation over another (pressure $v s$ volume control ventilation). ${ }^{53}$ While they did report that pressure support ventilation was found to be superior to pressure control ventilation in terms of oxygenation and postoperative lung function, this study was carried out in obese patients undergoing minor surgery with LMAs as the primary airway. The use of LMAs as the primary airway device during minor surgery is not routinely practised in many centres, and as mentioned previously, obesity is considered a relative contraindication to the use of LMAs.

\section{Extubation and postoperative oxygenation}

Emergence from anesthesia, extubation, and recovery

Airway complications and issues with oxygenation may present immediately on emergence from anesthesia at the time of tracheal extubation or may become manifest only in the postanesthesia care unit, resulting in significant morbidity and mortality. ${ }^{8}$ Analysis of the American Society of Anesthesiologists Closed Claims Project 
database of causes of death or brain death showed that $17 \%$ of the cases (26/156) occurred at time of tracheal extubation and recovery, and $58 \%$ of the extubation claims $(15 / 26)$ were encountered in obese patients. ${ }^{54}$ Consequently, careful consideration should be made for the planning and execution of this procedure and for management during the recovery period to minimize patient risk.

The Difficult Airway Society published guidelines in 2012 for management of tracheal extubation using a stepwise approach. ${ }^{55}$ Patients with obesity and obstructive sleep apnea are stratified into a category of extubation "at risk" of a major complication. Recommendations for awake tracheal extubation in this patient population include patient optimization (full reversal of neuromuscular blockade and return of protective airway reflexes), preoxygenation, placing the patient in a reverse Trendelenburg or semi-recumbent position, and suctioning of the oropharynx under direct vision. Logistic factors to be considered include selecting the operating room as the location for extubation and having skilled assistance, equipment (difficult airway trolley), and monitoring (in particular capnography) available. The Difficult Airway Society guidelines also advocate the placement of an airway exchange catheter in patients for whom tracheal re-intubation is likely to be difficult.

\section{Postoperative atelectasis and management}

Morbidly obese patients are at risk of significant atelectasis under general anesthesia that persists into the immediate postoperative period. Eichenberger et al. compared pulmonary atelectasis in non-obese and morbidly obese patients undergoing laparoscopic surgery using computerized tomography before induction, immediately post tracheal intubation, and $24 \mathrm{hr}$ after general anesthesia. $^{56}$ Morbidly obese patients showed significantly more atelectasis at all three stages compared with non-obese patients. Importantly, the amount of atelectasis (9.7\% total lung area) at $24 \mathrm{hr}$ remained unchanged in the morbidly obese group, while there was complete resolution in the non-obese patient group. Frequent episodes of hypoxemia in the first $24 \mathrm{hr}$ post laparoscopic bariatric surgery have also been observed in morbidly obese patients (with or without obstructive sleep apnea) receiving supplemental oxygen therapy. ${ }^{5}$ Studies comparing interventions to improve postoperative lung function include the application of CPAP via the Boussignac system and the use of respiratory physical therapy in the postanesthesia care unit. Wong et al. compared the Boussignac CPAP mask with the Venturi face mask in morbidly obese patients undergoing laparoscopic bariatric surgery, and study results showed an improved postoperative $\mathrm{PaO}_{2} / \mathrm{F}_{\mathrm{I}} \mathrm{O}_{2}$ ratio in the former group, while the percent of forced expiratory volume and the percent of forced vital capacity were comparable in both groups. ${ }^{57}$ These findings suggest that improvement in oxygenation using the Boussignac system resulted from a combination of higher $\mathrm{F}_{\mathrm{I}} \mathrm{O}_{2}$ and superior ventilation/ perfusion matching. In a study comparing the timing of application of the Boussignac system, better maintenance of spirometry lung function at $24 \mathrm{hr}$ was observed when the system was applied immediately post tracheal extubation vs a delayed start in the postanesthesia care unit. ${ }^{58}$ Incentive spirometry performed immediately following extubation and within the first two postoperative hours has been shown to enhance pulmonary function in obese patients up to $24 \mathrm{hr}$ post surgery. ${ }^{59}$ This simple effective deep breathing exercise warrants consideration when CPAP systems are not readily available. To summarize, morbidly obese patients are at high risk of hypoxemia up to $24 \mathrm{hr}$ postoperatively. Vigilance should be exercised, incentive spirometry provided, and CPAP administered as indicated in this patient population.

\section{Conclusion}

In the obese patient, reduced functional residual capacity and atelectasis predispose to rapid oxygen desaturation, and challenges in oxygenation and ventilation may persist throughout the perioperative period. Techniques to optimize oxygenation include various preoxygenation methods, head-up positioning at induction, use of intraoperative alveolar recruitment maneuvers combined with PEEP, CPAP mask application post tracheal extubation, and use of incentive spirometry.

Difficulties in mask ventilation, SGA use, tracheal intubation, and cricothyroidotomy should be assessed and anticipated. Awake tracheal intubation should be considered in cases where a higher suspicion of difficulty is anticipated with these four aspects of airway management. Strategies to optimize airway management include ramp position for intubation, availability of multiple airway equipment, and application of an algorithm for difficult airway management. Tracheal extubation over an airway exchange catheter should be considered for those patients in whom difficult tracheal intubation was encountered.

\section{Clinical case}

A 54-yr-old morbidly obese woman (weight, $97 \mathrm{~kg}$; height, $152 \mathrm{~cm}$; body mass index, $42 \mathrm{~kg} \cdot \mathrm{m}^{-2}$ ) is scheduled for 
elective laparoscopic hemicolectomy for colon carcinoma. She has a history of controlled hypertension and hypothyroidism. She denies any reflux, respiratory, or cardiac symptoms. Airway assessment reveals a Mallampati grade 3, but the examination is otherwise unremarkable. Preoperative investigations reveal normal electrocardiogram and chest radiograph findings, and mildly obstructive pulmonary function tests (forced expiratory flow in one second/forced vital capacity is $70 \%$ ).

Upon arrival in the operating room, the patient is placed in a $25^{\circ}$ head-up ramped position, routine monitoring is applied, and intravenous and arterial cannulae are placed. Using a firmly fitting face mask, the patient is preoxygenated for three minutes with an oxygen inspired fraction $\left(\mathrm{F}_{1} \mathrm{O}_{2}\right)$ of 1.0. Vital signs show heart rate 74 beats $\cdot \mathrm{min}^{-1}, \mathrm{O}_{2}$ saturation $99 \%$, blood pressure $142 / 82 \mathrm{mmHg}$, and end-tidal carbon dioxide $\left(\mathrm{ETCO}_{2}\right) 34 \mathrm{mmHg}$. For induction of anesthesia, the patient receives midazolam $2 \mathrm{mg}$, fentanyl $100 \mu \mathrm{g}$, propofol $200 \mathrm{mg}$, and rocuronium $60 \mathrm{mg}$. Bag and mask ventilation is then commenced.

\section{Instructions for completing the continuing professional development (CPD) module}

1. Read the current article and the references indicated in bold.

2. Go to: http://www.cas.ca/Members/CPD-Online and select the current module (Airway management and oxygenation in obese patients).

3. Answer the multiple choice questions regarding the case scenario.

4. Once you have entered all of your answers, you will have access to experts' explanations for all the possible choices.

5. Participants may claim up to four hours of CPD, for a total of 12 credits under Section 3 of the CPD program of the Royal College of Physicians and Surgeons of Canada.

\section{La prise en charge des voies aériennes et l'oxygénation du patient obèse}

\author{
Résumé \\ Objectif L'objectif de ce module de développement \\ professionnel continu est de décrire les difficultés \\ anatomiques et physiologiques rencontrées lors de la \\ prise en charge de patients obèses, de passer en revue \\ leurs effets sur l'oxygénation et la prise en charge des voies
}

aériennes, et de proposer des stratégies de prise en charge pour la période périopératoire.

Constatations principales La combinaison d'une accumulation excessive de tissu adipeux, de l'augmentation de la consommation d'oxygène, de la réduction de la capacité pulmonaire et d'une résistance accrue des voies aériennes chez les patients obèses augmente le risque de voies aériennes difficiles et de désaturation en oxygène rapide au cours de la période périopératoire. La préoxygénation peut être optimisée en élevant la tête du patient ou en le plaçant en position de Trendelenburg inversée, en exerçant une ventilation à pression positive continue et en fournissant une aide inspiratoire. Des difficultés peuvent survenir lors de la ventilation au ballon et au masque. La meilleure façon de parvenir à une bonne exposition laryngée pendant la laryngoscopie directe consiste à mettre le patient en position 'inclinée'. Les bougies et mandrins d'intubation peuvent faciliter l'intubation trachéale lorsque la vue laryngée est sous-optimale, et la vidéolaryngoscopie pourrait améliorer la vue de la glotte et augmenter les chances de succès de l'intubation trachéale. Les dispositifs supraglottiques à double lumière de nouvelle génération permettent des pressions de fuite plus élevées et pourraient être plus sécuritaires pour la prise en charge des patients obèses; en outre, ils peuvent également servir de guide pour l'intubation avec bronchoscope. Dans le cas de patients chez lesquels on prévoit des voies aériennes difficiles, une intubation trachéale vigile devrait être planifiée. En période peropératoire, les stratégies de ventilation telles que les manœuvres de recrutement en pression positive télé-expiratoire pourraient réduire l'atélectasie et améliorer l'oxygénation. Lors de l'extubation trachéale, une position de la tête élevée et une ventilation à pression positive continue réduisent l'hypoxémie en postopératoire. Après une intubation trachéale difficile, l'extubation sur un échangeur de tube devrait être envisagée. Conclusion Une désaturation en oxygène rapide est possible chez le patient obèse. Les difficultés potentielles de prise en charge des voies aériennes devraient être évaluées et anticipées, et des stratégies d'oxygénation, de ventilation et de prise en charge des voies aériennes devraient être optimisées pendant la période périopératoire.

\section{Objectifs de ce module de développement professionnel continu (DPC)}

Après avoir lu ce module, le lecteur devrait être en mesure de:

1. Décrire les changements de l'anatomie et de la physiologie respiratoire associés à l'obésité.

2. Reconnaitre les défis possibles en matière de ventilation au masque, d'utilisation de dispositifs 
supraglottiques, de l'intubation trachéale, et d'accès chirurgical aux voies aériennes chez le patient obèse.

3. Appliquer certaines techniques visant à optimiser l'induction de l'anesthésie générale chez le patient obèse.

4. Prévoir la méthode, le matériel et les dispositifs de secours nécessaires à établir la perméabilité des voies aériennes chez le patient obèse.

5. Anticiper les difficultés à parvenir à une ventilation optimale du patient obèse sous anesthésie générale et envisager des stratégies de ventilation pour minimiser les complications.

6. Optimiser les conditions pour réaliser une extubation trachéale sécuritaire chez le patient obèse.

Selon le rapport Obésité au Canada 2011, approximativement un adulte sur quatre au Canada (24,3-25,4 \%) est obèse. En 2008, on estimait l'impact économique de l'obésité à 4,6 milliards $\$$. $^{1}$ Le nombre de patients obèses devant subir une chirurgie ne cesse d'augmenter. On définit l'obésité comme un indice de masse corporelle (IMC) calculé $>30 \mathrm{~kg} \cdot \mathrm{m}^{-2}$, et l'obésité morbide comme un IMC $>40 \mathrm{~kg} \cdot \mathrm{m}^{-2}$. La masse corporelle totale et la distribution régionale du tissu adipeux en excès influencent le risque qu'une personne court de souffrir des nombreuses comorbidités associées à l'obésité. L'évaluation préopératoire joue donc un rôle crucial pour identifier de telles comorbidités et permet d'optimiser la prise en charge médicale, le cas échéant, ainsi que de planifier le déroulement de la période périopératoire afin de minimiser la morbidité et la mortalité. $^{2}$ Ce module de développement professionnel continu traite principalement de la prise en charge des voies aériennes et de l'oxygénation du patient obèse subissant une anesthésie générale.

\section{Perméabilité des voies aériennes et physiologie respiratoire du patient obèse}

Chez le patient obèse, l'impact des changements anatomiques et physiologiques sur l'oxygénation et la prise en charge des voies aériennes est une considération importante dans le contexte périopératoire (tableau). Les dépôts de tissu adipeux dans les structures pharyngées (principalement le long des parois pharyngées latérales) débordent dans la lumière des voies aériennes, ce qui entraîne un rétrécissement de la filière, particulièrement lors de l'inspiration. ${ }^{3}$ La combinaison d'une grosse langue, d'un excès de tissu mou dans les voies aériennes supérieures et d'une réduction du fonctionnement $\mathrm{du}$ muscle dilatateur du pharynx pendant les périodes de somnolence prédispose le patient obèse à l'apnée
Tableau Impact des changements anatomiques et physiologiques chez le patient obèse sur l'oxygénation et la prise en charge des voies aériennes

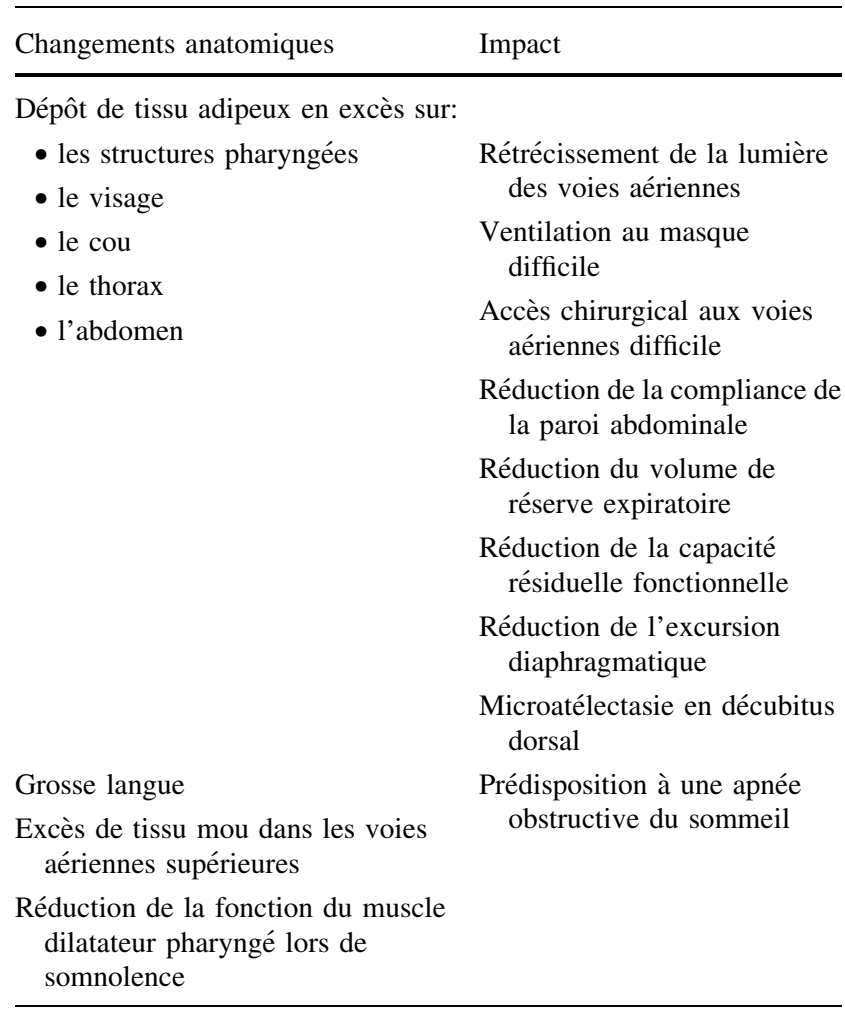

Changements physiologiques

au niveau respiratoire

Ventilation

Augmentation de la fréquence respiratoire

Réduction du volume courant

Augmentation de la ventilation minute

Oxygénation

Élargissement du gradient alvéolaire-artériel (A-a)

Augmentation de la consommation d'oxygène

Hypoxémie légère

Capacité pulmonaire

Réduction du volume de réserve expiratoire (VRE)

Réduction de la capacité résiduelle fonctionnelle (CRF)

Réduction modeste de la capacité pulmonaire totale (CPT)

Réduction modeste du volume résiduel (VR)

La CRF s'approche du VR

La capacité de fermeture pourrait dépasser la CRF lors de respiration normale

Compliance

Réduction de la compliance de la paroi abdominale

Réduction de la compliance pulmonaire 
Tableau continued

Changements physiologiques

au niveau respiratoire

Fonction respiratoire

Réduction minime de la VEMS ou
de la CVF
Rapport VEMS/CVF en général
préservé
Augmentation de la résistance des
voies aériennes (attribuée à la
réduction de la capacité
pulmonaire, à la fermeture des
voies aériennes de petit calibre,
et au remodelage des voies
aériennes par les adipokines
pro-inflammatoires)

VEMS = volume expiratoire maximal en une seconde; $\mathrm{CVF}=$ capacité vitale forcée

obstructive du sommeil (AOS). ${ }^{4}$ Il a été démontré que les patients obèses morbides, qu'ils soient atteints d'AOS ou non, souffraient d'épisodes fréquents de désaturation en oxygène après une chirurgie bariatrique par laparoscopie et ce, malgré l'oxygénothérapie. ${ }^{5}$

Parmi les changements au niveau de la physiologie respiratoire, citons une augmentation de la consommation d'oxygène, une fréquence respiratoire plus élevée, une réduction de la capacité pulmonaire (et tout particulièrement de la capacité résiduelle fonctionnelle), une ventilation minute significativement plus élevée, une réduction de la compliance totale du système respiratoire et une résistance accrue des voies aériennes (tableau). ${ }^{6}$ L'association entre obésité et élargissement du gradient d' $\mathrm{O}_{2}$ alvéolaire-artériel semble être due à une inadéquation ventilation-perfusion provoquée par une microatélectasie, particulièrement lorsque le patient est en position dorsale. Après l'induction de l'anesthésie générale chez les patients obèses morbides, la capacité résiduelle fonctionnelle diminue d'environ $50 \%$ par rapport aux valeurs préanesthésie. Cette diminution est nettement plus importante que celle de $20 \%$ observée chez les patients non obèses. Ces changements physiologiques prédisposent le patient obèse morbide à une désaturation en oxygène rapide avec l'apparition de l'apnée.

\section{Association entre obésité et voies aériennes difficiles}

Le terme de «voies aériennes difficiles » englobe les difficultés rencontrées lors d'une ventilation au masque, avec les dispositifs supraglottiques, lors de l'intubation trachéale, et/ou pour l'accès chirurgical aux voies aériennes. L'excès de tissu adipeux sur le visage, le cou, la poitrine, le thorax et l'abdomen peut poser des défis considérables en ce qui touche aux voies aériennes: le positionnement du patient, l'extension du cou, la ventilation au ballon et au masque, l'intubation trachéale, l'oxygénation et la trachéotomie peuvent tous être problématiques. Le quatrième Projet d'audit national (National Audit Project - NAP4) du Royaume-Uni a passé en revue les complications majeures de prise en charge des voies aériennes (décès, lésion cérébrale, accès chirurgical d'urgence aux voies aériennes, admission imprévue aux soins intensifs, et séjour prolongé à l'unité des soins intensifs) et rapporte un risque quatre fois plus élevé de complications graves chez les patients obèses morbides que chez les patients non obèses. ${ }^{8,9}$ Dix-neuf (25\%) des 77 patients obèses passés en revue dans cette étude ont souffert d'une lésion cérébrale ou sont décédés. L'étude rapporte qu'au cours de l'anesthésie, l'intubation trachéale a été difficile chez 23 patients, une inhalation est survenue chez huit patients, sept patients ont connu des problèmes lors de l'extubation trachéale, et quatre patients ont souffert d'un traumatisme des voies aériennes.

\section{La ventilation au masque}

L'obésité a été identifiée comme un prédicteur indépendant de ventilation au masque difficile. Dans une étude prospective portant sur 1502 patients consécutifs devant subir une chirurgie sous anesthésie générale, les anesthésiologistes ont éprouvé des difficultés lors de la ventilation au masque dans 75 cas, mais les difficultés n'avaient été anticipées que pour $17 \%$ de ces cas (13 patients). ${ }^{10}$ En se fondant sur une analyse multivariée, on a déterminé qu'un IMC $>26 \mathrm{~kg} \cdot \mathrm{m}^{-2}$ était l'un de cinq prédicteurs indépendants de difficultés lors de la ventilation au masque. ${ }^{10}$ Un compte rendu rapportant 22660 tentatives de ventilation au masque a déterminé qu'un IMC $>30 \mathrm{~kg} \cdot \mathrm{m}^{-2}$ était un prédicteur indépendant de ventilation au masque difficile et un prédicteur indépendant de ventilation au masque difficile ou impossible et d'intubation trachéale difficile. ${ }^{11}$ Toutefois, une autre étude portant sur plus de 50000 anesthésies n'a pas identifié l'obésité comme prédicteur indépendant de ventilation au masque impossible. ${ }^{12}$ Dans cette étude, ${ }^{12}$ une radiothérapie du cou, le sexe masculin, la présence d'une barbe et des scores de Mallampati de 3 ou 4 ont été identifiés comme prédicteurs indépendants d'une ventilation au masque impossible. Pour résumer, l'obésité est associée à une ventilation au masque potentiellement difficile; par conséquent, qu'on anticipe ou non une ventilation au masque difficile, des dispositifs supraglottiques devraient être à portée de votre main lors de l'induction de l'anesthésie. 


\section{Les dispositifs supraglottiques}

Les dispositifs supraglottiques sont couramment utilisés lors de la prise en charge des voies aériennes non urgente et urgente, mais que sont le taux de réussite et la sécurité de tels dispositifs chez le patient obèse? Dans une population d'étude de plus de 15000 patients, on a découvert que l'obésité était un prédicteur indépendant d'échec d'utilisation du masque laryngé Unique ${ }^{\mathrm{TM}}$, nécessitant le retrait de l'instrument et une intubation endotrachéale. La ventilation était inadaptée en raison de fuites ou d'obstruction des voies aériennes dans $42,4 \%$ et $30 \%$ des cas de complications au niveau des voies aériennes, respectivement. ${ }^{13}$ Il a été démontré que les dispositifs supraglottiques à double lumière avec conduit gastrique offraient une ventilation efficace chez les patients obèses morbides lorsqu'ils étaient utilisés comme pont avant une intubation trachéale à l'aide d'un laryngoscope. En outre, lorsque les dispositifs supraglottiques étaient comparés à une ventilation par masque facial réalisée par des novices, les dispositifs supraglottiques entraînaient de meilleurs scores de ventilation et permettaient une ventilation considérablement plus facile. ${ }^{14,15}$ Les dispositifs supraglottiques à double lumière, comme les masques laryngés ProSeal $^{\mathrm{TM}}$ et Supreme ${ }^{\mathrm{TM}}$, fournissent des pressions de fuite plus élevées et pourraient donc être plus sécuritaires chez les patients obèses ${ }^{16}$ toutefois, il faut retenir que les dispositifs supraglottiques ne protègent pas les voies aériennes de l'inhalation. Huit des 23 cas d'inhalation de contenu gastrique pendant l'anesthésie - la principale complication au niveau des voies aériennes rapportée dans l'étude NAP4 - sont survenus chez des patients obèses. ${ }^{8}$ En tout, huit patients sont décédés et deux patients ont souffert de lésions cérébrales à la suite d'inhalation de contenu gastrique. ${ }^{9}$ L'obésité est donc une contre-indication relative à l'utilisation de dispositifs supraglottiques et il faut faire preuve de prudence lors de leur utilisation.

\section{La laryngoscopie directe et l'intubation}

La laryngoscopie directe ou l'intubation trachéale sont-elles plus difficiles chez un patient obèse? Juvin et coll. ont rapporté un taux de 15,5\% d'intubation trachéale difficile chez les patients obèses, comparativement à $2,2 \%$ chez des patients sveltes. ${ }^{17}$ Alors que certaines études ont montré une association entre obésité et intubation difficile, la controverse demeure. En effet, les données probantes sont insuffisantes pour soutenir que l'IMC seul est un prédicteur indépendant de laryngoscopie difficile ou d'intubation difficile. ${ }^{17,18}$ Dans une étude de cohorte portant sur 91332 patients consécutifs, on a observé qu'un IMC $>35 \mathrm{~kg} \cdot \mathrm{m}^{2}$ était un prédicteur significatif d'un point de vue statistique d'intubation difficile ou d'échec à l'intubation. ${ }^{19}$ À l'inverse, Erzi et coll. ont découvert que l'IMC n'était pas un prédicteur indépendant d'une mauvaise visualisation de la glotte par laryngoscopie directe $;{ }^{20}$ toutefois, dans cette étude, la combinaison de l'IMC et d'une anomalie au niveau des dents supérieures était un prédicteur significatif de laryngoscopie difficile. ${ }^{20}$ Erzi et coll. ont fait appel à l'échographie pour déterminer la quantité de tissu mou du cou antérieur au niveau des cordes vocales. Ce faisant, les auteurs ont observé que les patients obèses morbides chez qui la laryngoscopie était difficile avaient davantage de tissu mou prétrachéal et une circonférence du cou plus importante que les patients chez qui la laryngoscopie n'avait pas posé de problème. L'épaisseur du tissu mou prétrachéal était [moyenne (ÉT)] $28 \quad(2,7) \mathrm{mm}$ vs. 17,5 $(1,8) \mathrm{mm}$, respectivement $(P<0,001)$, et la circonférence du cou était de $50(3,8) \mathrm{cm}$ vs. 43,5 $(2,2) \mathrm{cm}$, respectivement $(P<$ $0,001){ }^{21}$ Selon Komatsu et coll., l'augmentation du tissu prétrachéal ne constitue pas un bon prédicteur de laryngoscopie difficile chez les patients obèses; toutefois, la circonférence du cou des patients de cette étude était comparativement plus basse $[43,5(4,7) \mathrm{cm} v s .44,3(5,3) \mathrm{cm}$; $P<0,5]$ dans les groupes laryngoscopie difficile et laryngoscopie facile, respectivement. Des études supplémentaires sont nécessaires pour clarifier le rôle de l'échographie et de la quantification du tissu adipeux prétrachéal en tant que prédicteur de laryngoscopie difficile.

La vue obtenue par laryngoscopie directe pourrait être affectée par le positionnement du patient et peut être améliorée en alignant le méat auditif externe à l'échancrure sternale, comme nous l'expliquerons plus bas. ${ }^{23}$ La mésentente générale quant à savoir si l'intubation trachéale est plus difficile chez les patients obèses morbides pourrait être due à des facteurs confondants particuliers, notamment des variations au niveau de la définition d'une intubation difficile (plus de trois tentatives, échelle de difficulté d'intubation $>5$ ) et d'une laryngoscopie difficile (grade $\geq 3$ selon la classification de Cormack et Lehane), de la position du patient, de l'expérience de l'opérateur, et de la technique de laryngoscopie (laryngoscopie directe ou vidéolaryngoscopie). Toutefois, les spécialistes s'entendent pour dire qu'une combinaison de plusieurs éléments, tels un score de Mallampati $\geq 3$ et une circonférence plus importante du cou chez le patient obèse, augmente le risque de laryngoscopie difficile et d'intubation trachéale difficile. ${ }^{24,25}$

\section{L'accès chirurgical aux voies aériennes}

Dans les situations où il est «impossible d'intuber, impossible de ventiler », une cricothyroïdotomie peut être particulièrement difficile à réaliser chez un patient obèse en 
raison de la difficulté à identifier les repères anatomiques usuels. Aslani et coll. ont étudié la capacité des médecins à repérer correctement la membrane cricothyroïdienne chez des patientes obèses $(n=15)$ et non obèses $(n=41)$ chez lesquelles la membrane avait été identifiée au préalable par échographie. La membrane cricothyroïdienne a été correctement identifiée chez $1 / 15$ patiente obèse et $12 / 41$ patientes non obèses. ${ }^{26}$ Le nouveau rôle que l'échographie joue pour l'identification de l'anatomie des voies aériennes présente l'avantage qu'elle transforme une technique jusque-là réalisée en aveugle en une technique guidée. ${ }^{27}$ En outre, l'échographie permet d'identifier précisément la membrane cricothyroïdienne chez les patients possédant une imposante circonférence du cou et des repères impalpables, indépendamment de l'expérience du médecin. ${ }^{28}$

Étant donné les défis auxquels nous pourrions être confrontés lors de la ventilation au masque, de l'utilisation de dispositifs supraglottiques, de l'intubation trachéale et de la cricothyroïdotomie chez le patient obèse morbide, il est recommandé de faire preuve de prudence et d'envisager une intubation trachéale vigile pour les patients chez lesquels on anticipe des voies aériennes difficiles, ou dont les voies aériennes sont connues comme étant difficiles.

\section{La préparation optimale du patient pour l'induction de l'anesthésie}

\section{Positionnement et préoxygénation}

Un positionnement optimal du patient obèse est essentiel avant l'induction de l'anesthésie générale. Il a été démontré que les positions tête élevée à $25^{\circ}$ et Trendelenburg inversée augmentaient la durée de l'apnée sans désaturation comparativement au décubitus dorsal, augmentant ainsi le temps disponible pour l'intubation trachéale. ${ }^{29,30}$ Dans une étude randomisée contrôlée, la préoxygénation de patients obèses morbides en position tête élevée à $25^{\circ}$ a entraîné une tension en oxygène plus élevée de $23 \%$ qu'en décubitus dorsal [442 (104) mmHg vs. 360 (99) $\mathrm{mmHg}$, respectivement; $P=0,012)$ et une augmentation significative de la durée d'apnée avant désaturation [201 (55) sec vs. 155 (69) sec, respectivement; $P=0,023] .{ }^{29}$ La position de laryngoscopie avec la tête surélevée améliore l'exposition laryngée pendant la laryngoscopie directe. ${ }^{31}$ Chez le patient obèse, on y parvient en alignant horizontalement l'échancrure sternale et le méat auditif externe en position 'inclinée'. Afin d'obtenir cet alignement visuel, l'utilisation de plusieurs couvertures pliées et d'oreillers spéciaux disponibles sur le marché placés sous le haut du corps, les épaules et la tête ou le positionnement 'incliné' de la table ont été préconisés. ${ }^{23} \mathrm{Il}$ a aussi été démontré que la position dite de la 'chaise de plage' facilitait l'intubation (figure). ${ }^{18}$
L'induction de l'anesthésie générale est une période à risque élevé d'hypoxémie. Même avec une préoxygénation, on peut prévoir que la durée de l'apnée avant désaturation sera significativement plus courte chez le patient obèse morbide que chez un patient de poids normal. ${ }^{32} \mathrm{La}$ préoxygénation est considérée comme suffisante lorsque la fraction d'oxygène télé-expiratoire est $>90 \%{ }^{33} \mathrm{La}$ respiration en volume courant via un masque facial bien scellé pendant trois minutes ou quatre respirations en capacité vitale sont deux techniques de préoxygénation courantes. Les données probantes laissent penser que les patients obèses désaturent plus rapidement avec la seconde technique. ${ }^{34}$ Parmi les autres techniques d'oxygénation péri-induction, citons l'insufflation nasopharyngée d'oxygène supplémentaire, la position semi-assise, la ventilation à pression positive continue (CPAP), la pression positive télé-expiratoire (PEEP) et l'aide inspiratoire - appliquées avant l'induction de l'anesthésie générale chez un patient respirant spontanément. ${ }^{28-31}$ Baraka et coll. ont comparé une technique de préoxygénation suivie par l'insufflation nasopharyngée d'oxygène (groupe à l'étude) à une technique de préoxygénation seule (groupe témoin) chez des patients obèses morbides positionnés avec la tête élevée à un angle de $25^{\circ} .{ }^{35}$ Dans le groupe à l'étude, 16 des 17 patients ont maintenu leur saturation en oxygène à $100 \%$ pendant quatre minutes d'apnée. Les 17 patients du groupe témoin ont subi une désaturation en oxygène de 100 à $95 \%$ en un temps moyen de 145 (27) sec. Il a été démontré que le recours à une ventilation en pression positive continue / pression positive télé-expiratoire de $10 \mathrm{~cm} \mathrm{H}_{2} \mathrm{O}$ (CPAP / PEEP) tout au long de la période d'induction (CPAP lors de la respiration et PEEP après l'apnée) augmentait la durée de l'apnée avant désaturation de $50 \%$ chez les patients obèses morbides. ${ }^{36,37}$ En outre, il a également été démontré que la ventilation en pression positive non effractive utilisant une aide inspiratoire et une PEEP via un masque facial améliorait la préoxygénation, résultant en une augmentation plus rapide et un $\mathrm{O}_{2}$ télé-expiratoire plus élevé comparativement à une préoxygénation en ventilation spontanée. ${ }^{38}$

\section{Choix de la technique d'intubation}

\section{Laryngoscopie directe ou indirecte}

Le positionnement optimal du patient augmentera les chances de réussite de l'intubation trachéale par laryngoscopie directe. L'utilisation d'une bougie (Eschmann $^{\mathrm{TM}}$ ou Frova ${ }^{\mathrm{TM}}$ ) ou d'un mandrin souple pour favoriser l'intubation devrait être envisagée lorsqu'on n'obtient qu'une vue sous-optimale de l'ouverture du larynx. ${ }^{39,40}$ 
Sinon, une laryngoscopie indirecte peut être réalisée à l'aide d'un vidéolaryngoscope ou d'un laryngoscope optique. On contourne ainsi la nécessité d'aligner les axes oral et pharyngé. Dans une étude comparant la vidéolaryngoscopie à la laryngoscopie directe chez 318 patients obèses morbides, le Airtraq $^{\mathrm{TM}}$ et le masque laryngé $\mathrm{CTrach}^{\mathrm{TM}}$ ont fourni un accès définitif aux voies aériennes plus rapidement et un temps d'apnée plus court, respectivement, que le laryngoscope conventionnel Macintosh. ${ }^{41}$ Lors du recours aux techniques assistées par vidéo, les scores d'ouverture glottique (POGO) étaient significativement plus élevés que lors de l'utilisation de la laryngoscopie directe $(97 \%$ vs. $75 \%$, respectivement; $P<0,01)$. Andersen et coll. ont également observé que le vidéolaryngoscope Glidescope ${ }^{\circledR}$ fournissait de meilleures vues de la glotte et des scores de difficulté d'intubation plus bas que le laryngoscope Macintosh chez les patients obèses morbides. ${ }^{42}$ Bien qu'une vue optimale de l'ouverture laryngée ne se traduise pas forcément par une intubation plus facile, la progression de la sonde endotrachéale peut bénéficier de l'utilisation d'un canal guide placé sur le dispositif laryngé ou sur une bougie. Malgré le nombre croissant d'outils d'intubation disponibles, aucun vidéolaryngoscope ne s'est avéré supérieur aux autres pour l'intubation du patient obèse; toutefois, les vidéolaryngoscopes fournissent une meilleure vue laryngée et devraient être disponibles pour la prise en charge des voies aériennes.

\section{Les aides à l'intubation: le recours aux dispositifs supraglottiques}

Chez un patient anesthésié, l'intubation par fibroscope pourrait être entravée par la perte de tonus des voies aériennes supérieures et la tendance à l'effondrement des voies aériennes. Non seulement les dispositifs supraglottiques facilitent-ils l'oxygénation et la ventilation des poumons, mais ils servent également de guides ou de tuteurs pour maintenir les voies aériennes perméables et, possiblement, permettent d'améliorer la visualisation des cordes vocales et l'accès au larynx en présence de sécrétions et/ou de sang. ${ }^{43}$ Plusieurs techniques ont été décrites. Une sonde endotrachéale peut être guidée sur un bronchoscope à travers le dispositif supraglottique et positionnée en vision directe avant de retirer le bronchoscope. Autrement, un échangeur de tube Aintree (Cook Critical Care, Bloomington, IN, USA) peut être guidé sur le bronchoscope dans la trachée à travers le dispositif supraglottique. Le bronchoscope, puis le dispositif supraglottique sont retirés, laissant l'échangeur en place afin de servir de guide pour le positionnement de la sonde endotrachéale (taille maximale de la sonde, 7,0 $\mathrm{mm}$ de diamètre interne). Cette technique a été décrite chez le patient éveillé et le patient anesthésié avec voies aériennes difficiles. $^{44,45}$ Lorsqu'on a comparé l'utilisation d'un masque laryngé d'intubation (c.-à-d. le Fastrach ${ }^{\mathrm{TM}}$ ) chez des patients sveltes et obèses morbides, le dispositif s'est avéré efficace pour l'intubation dans les deux populations de patients, les patients obèses nécessitant significativement moins de manœuvres de repositionnement du dispositif. ${ }^{46}$

\section{Utilisation d'un bronchoscope et d'un vidéolaryngoscope pour l'intubation vigile}

En pratiquant une intubation trachéale vigile, on permet l'accès aux voies aériennes d'un patient respirant spontanément avant l'induction de l'anesthésie. Cette approche permet de contourner certaines des difficultés qui pourraient se présenter sous anesthésie générale. C'est pourquoi une intubation vigile devrait être envisagée chez les patients présentant des antécédents ou des prédicteurs cliniques de ventilation au masque difficile, de laryngoscopie difficile, ou de cricothyroïdotomie chirurgicale. L'intubation avec un bronchoscope flexible nécessite à la fois formation et expérience et pourrait s'avérer difficile chez le patient obèse morbide en raison des changements anatomiques présentés plus haut. La préparation du patient pour une intubation trachéale vigile comprend son positionnement optimal (en position 'inclinée' ou de Trendelenburg inversée) et la préoxygénation, comme cela a déjà été mentionné. On peut faciliter l'accès et la visualisation des voies aériennes pharyngées en dégageant la langue, en déplaçant la mâchoire inférieure vers l'avant et en insérant une canule (par ex. les canules Ovassapian, Berman et Williams). Les avantages que présente un passage plus direct du bronchoscope par voie nasale dans le pharynx doivent être soupesés avec le risque d'épistaxis. L'utilisation d'un anesthésique local topique sur les voies aériennes pour en émousser les réflexes, avec ou sans sédation consciente, améliorera la tolérance du patient. Le recours à une intubation trachéale vigile par vidéolaryngoscopie a également été décrit dans la littérature comme alternative à l'intubation avec un bronchoscope flexible. $^{47}$

\section{Stratégies de ventilation et considérations peropératoires}

Il a été démontré que la ventilation mécanique et la curarisation entravaient la fonction pulmonaire, la compliance pulmonaire et l'échange gazeux chez le patient obèse sous anesthésie générale, en raison de la réduction de la capacité pulmonaire et de l'atélectasie. ${ }^{48}$ Ces conséquences pourraient être encore exacerbées par un pneumopéritoine et le positionnement du patient pour la chirurgie (décubitus dorsal, lithotomie et position de Trendelenburg). Il faut porter une attention particulière aux 
stratégies de ventilation destinées à minimiser ces complications. Dans une étude de tomodensitométrie portant sur des patients obèses morbides sous anesthésie générale, la combinaison d'une manœuvre de recrutement à $55 \mathrm{~cm} \mathrm{H}_{2} \mathrm{O}$ pendant $10 \mathrm{sec}$ suivie d' une PEEP à $10 \mathrm{~cm} \mathrm{H}_{2} \mathrm{O}$ a réduit l'atélectasie et amélioré l'oxygénation davantage que l'une ou l'autre manœuvre réalisée seule. ${ }^{50}$ Les patients obèses chez lesquels on réalise une manœuvre de capacité vitale (MCV) de $40 \mathrm{~cm} \mathrm{H}_{2} \mathrm{O}$ pendant sept à huit secondes suivie de PEEP à $10 \mathrm{~cm} \mathrm{H}_{2} \mathrm{O}$ ont affiché une meilleure oxygénation peropératoire et postopératoire, et leurs scores d'atélectasie étaient plus bas sur la tomodensitométrie thoracique deux heures après l'opération comparativement à des patients obèses ne bénéficiant que d'une $\mathrm{MCV} .{ }^{51} \mathrm{Chez}$ les patients obèses subissant une chirurgie laraposcopique d'anneau gastrique, Almarakbi et coll. ont également observé une compliance respiratoire et une $\mathrm{PaO}_{2}$ supérieures avec des manœuvres de recrutement inspiratoire répétées $\left(40 \mathrm{~cm} \mathrm{H}_{2} \mathrm{O}\right.$ pendant $15 \mathrm{sec}$ toutes les dix minutes) suivies de PEEP $\left(10 \mathrm{~cm} \mathrm{H}_{2} \mathrm{O}\right) .{ }^{52}$ Les patients obèses peuvent nécessiter des pressions de pointe lors de l'application d'une PEEP de $10 \mathrm{~cm} \quad \mathrm{H}_{2} \mathrm{O}$ après des manœuvres de recrutement. Alors qu'aucun barotraumatisme n'a été rapporté dans ces études, il convient d'être prudent. Dans un compte rendu de Silva $e t$ coll. examinant la ventilation mécanique chez des patients obèses, les auteurs recommandent des manœuvres de recrutement progressives afin de réduire l'instabilité hémodynamique et n'ont découvert aucune donnée probante appuyant l'utilisation d'un mode de ventilation plutôt que d'un autre (ventilation en pression contrôlée $v s$. en volume contrôlé). ${ }^{53}$ Bien que les auteurs aient rapporté que l'aide inspiratoire était supérieure à la ventilation en pression contrôlée en termes d'oxygénation et de fonction pulmonaire postopératoire, cette étude portait sur des patients obèses subissant une chirurgie mineure avec un masque laryngé comme principal dispositif pour les voies aériennes. L'utilisation d'un masque laryngé pour la prise en charge des voies aériennes pour une chirurgie mineure n'est pas une pratique courante dans de nombreux centres et, comme nous l'avons mentionné précédemment, l'obésité est considérée comme une contre-indication relative à son utilisation.

\section{L'extubation et l'oxygénation postopératoire}

\section{L'émergence de l'anesthésie, l'extubation et le réveil}

Les complications au niveau des voies aériennes et les problèmes d'oxygénation pourraient survenir immédiatement à l'émergence de l'anesthésie, au moment de l'extubation trachéale, ou elles pourraient se manifester seulement en salle de réveil, entraînant une morbidité et une mortalité significatives. ${ }^{8}$ L'analyse de la base de données du Closed Claims Project, littéralement le 'Projet des réclamations réglées', de l'American Society of Anesthesiologists portant sur les causes de décès ou de mort cérébrale a montré que $17 \%$ des cas (26/156) sont survenus au moment de l'extubation trachéale et du réveil, et $58 \%$ des plaintes en matière d'extubation $(15 / 26)$ sont survenues chez des patients obèses. ${ }^{54} \mathrm{Il}$ est donc important de bien réfléchir à la planification et à l'exécution de cette intervention et à la prise en charge pendant la période de réveil, afin de minimiser les risques pour le patient.

En 2012, la Difficult Airway Society a publié des directives pour la prise en charge de l'extubation trachéale avec une approche progressive. ${ }^{55}$ Les patients souffrant d'obésité et d'apnée obstructive du sommeil sont stratifiés dans une catégorie d'extubation 'à risque' de complications majeures. Parmi les recommandations pour l'extubation trachéale vigile chez cette population de patients, citons la préparation optimale du patient (neutralisation complète du bloc neuromusculaire et rétablissement des réflexes protecteurs des voies aériennes), la préoxygénation, le positionnement du patient en position de Trendelenburg inversée ou en position semi-assise, et l'aspiration de l'oropharynx sous vision directe. Les facteurs logistiques dont il faut en outre tenir compte comprennent le choix de la salle d'opération comme lieu d'extubation, la présence de personnes compétentes, la disponibilité de matériel adéquat (chariot pour les voies aériennes difficiles), et le monitorage (en particulier la capnographie). Les directives de la Difficult Airway Society recommandent également de placer un échangeur de tube chez les patients pour lesquels une réintubation trachéale serait probablement difficile.

\section{L'atélectasie postopératoire et sa prise en charge}

Les patients obèses morbides courent le risque de souffrir d'atélectasie grave sous anesthésie générale, laquelle persiste en période postopératoire immédiate. Eichenberger et coll. ont comparé l'atélectasie pulmonaire chez des patients non obèses et des patients obèses morbides subissant une chirurgie par laparoscopie à l'aide d'une tomodensitométrie avant l'induction, immédiatement après l'intubation trachéale, et $24 \mathrm{~h}$ après l'anesthésie générale. ${ }^{56} \mathrm{Il}$ y a eu significativement plus d'atélectasie chez les patients obèses morbides aux trois temps de mesure que chez les patients non obèses. Fait important, la quantité d'atélectasie $(9,7 \%$ de la surface pulmonaire totale) à $24 \mathrm{~h}$ est demeurée inchangée dans le groupe obèse morbide, alors qu'une résolution complète a été observée dans le groupe de patients non obèses. Des épisodes fréquents d'hypoxémie au cours des premières $24 \mathrm{~h}$ après une chirurgie bariatrique par laparoscopie ont également été observés chez les patients 
obèses morbides (avec ou sans apnée obstructive du sommeil) bénéficiant d'une oxygénothérapie. ${ }^{5}$ Les études comparant les interventions pour améliorer la fonction pulmonaire postopératoire incluent l'application d'une CPAP via le système Boussignac et l'utilisation de physiothérapie respiratoire en salle de réveil. Wong et coll. ont comparé le masque de CPAP de Boussignac au masque facial Venturi chez des patients obèses morbides subissant une chirurgie bariatrique par laparoscopie, et l'étude a montré une amélioration du rapport $\mathrm{PaO}_{2} / \mathrm{F}_{\mathrm{I}} \mathrm{O}_{2}$ en postopératoire dans le premier groupe, alors que le pourcentage de volume expiratoire maximal en une seconde et le pourcentage de capacité vitale forcée étaient comparables dans les deux groupes. ${ }^{57}$ Ces résultats suggèrent que l'amélioration de l'oxygénation observée avec le système de Boussignac était le résultat combiné d'une $\mathrm{F}_{\mathrm{I}} \mathrm{O}_{2}$ plus élevée et d'une meilleure adéquation ventilation/perfusion. Dans une étude visant à déterminer le moment où mettre en place le système de Boussignac, un meilleur maintien de la fonction pulmonaire telle que mesurée par spirométrie à $24 \mathrm{~h}$ a été observé lorsqu'on appliquait le système immédiatement après l'extubation trachéale plutôt que de retarder son début en salle de réveil. ${ }^{58}$ Il a été démontré qu'une spirométrie incitative réalisée immédiatement après l'extubation et au cours des deux premières heures postopératoires améliorait la fonction pulmonaire chez les patients obèses jusqu'à $24 \mathrm{~h}$ après la chirurgie. ${ }^{59}$ Cet exercice simple et efficace de respiration profonde mérite d'être envisagé lorsque les systèmes de CPAP ne sont pas à portée de main. Pour résumer, les patients obèses morbides courent un risque élevé d'hypoxémie jusqu'à $24 \mathrm{~h}$ après leur opération. Il faut faire preuve de vigilance, fournir une spirométrie incitative et administrer une CPAP tel qu'indiquée chez cette population de patients.

\section{Conclusion}

La réduction de la capacité résiduelle fonctionnelle et l'atélectasie observées chez un patient obèse le prédisposent à une désaturation en oxygène rapide. En outre, l'oxygénation et la ventilation peuvent demeurer difficiles tout au long de la période périopératoire. Parmi les techniques contribuant à améliorer l'oxygénation, citons diverses méthodes de préoxygénation, un positionnement avec la tête élevée lors de l'induction, l'utilisation de manœuvres peropératoires de recrutement alvéolaire combinées à une PEEP, l'application d'un masque de CPAP après l'extubation trachéale et le recours à une spirométrie incitative.

Les difficultés potentielles lors de la ventilation au masque, de l'utilisation de dispositifs supraglottiques, de l'intubation trachéale et de la cricothyroïdotomie devraient être évaluées et anticipées. L'intubation trachéale vigile devrait être envisagée dans les cas où les difficultés pour ces quatre aspects de la prise en charge des voies aériennes semblent plus importantes. Parmi les stratégies optimisant la prise en charge des voies aériennes, citons le positionnement incliné du patient pour l'intubation, la mise à disposition de plusieurs dispositifs de prise en charge des voies aériennes et l'application d'un algorithme pour la prise en charge des voies aériennes difficiles. L'extubation trachéale sur un échangeur de tube devrait être envisagée chez les patients dont l'intubation trachéale a été difficile.

\section{Cas clinique}

Une femme obèse morbide de 54 ans (poids, $97 \mathrm{~kg}$; taille, $152 \mathrm{~cm}$; indice de masse corporelle, $42 \mathrm{~kg} \cdot \mathrm{m}^{-2}$ ) se présente pour subir une hémicolectomie non urgente par laparoscopie pour traiter un carcinome du côlon. Elle a des antécédents d'hypertension contrôlée et d'hypothyroïdisme. Elle nie souffrir de reflux ou de symptômes respiratoires ou cardiaques. L'évaluation des voies aériennes révèle un score de Mallampati de grade 3, mais l'examen ne relève rien d'autre. Les examens préopératoires révèlent un électrocardiogramme et des radiographies des poumons normaux, ainsi que des tests de la fonction pulmonaire légèrement obstructifs (le volume expiratoire maximal en une seconde / capacité vitale forcée est de $70 \%$ ).

À son arrivée en salle d'opération, la tête de la patiente est relevée à $25^{\circ}$, le monitorage habituel est mis en place, et des canules intraveineuses et artérielles sont placées. À l'aide d'un masque facial ajusté, la patiente est préoxygénée pendant trois minutes avec une fraction d'oxygène inspiré $\left(\mathrm{F}_{\mathrm{I}} \mathrm{O}_{2}\right)$ de 1,0 . Les signes vitaux montrent une fréquence cardiaque de 74 battements. $\min ^{-1}$, une saturation en $\mathrm{O}_{2}$ à $99 \%$, une pression artérielle de 142/82 $\mathrm{mmHg}$, et un dioxyde de carbone télé-expiratoire $\left(\mathrm{ETCO}_{2}\right)$ de $34 \mathrm{mmHg}$. Pour l'induction de l'anesthésie, la patiente reçoit $2 \mathrm{mg}$ de midazolam, $100 \mu \mathrm{g}$ de fentanyl, $200 \mathrm{mg}$ de propofol et $60 \mathrm{mg}$ de rocuronium. On commence alors la ventilation au ballon et au masque.

\section{Directives pour compléter le module de développement professionnel continu (DPC)}

1. Lisez cet article et les références en gras.

2. Allez à: http://www.cas.ca/Membres/modules-de-DPC et choisissez le module actuel (La prise en charge des voies aériennes et l'oxygénation du patient obèse). 
3. Répondez aux questions à choix de réponses concernant le cas clinique.

4. Une fois que vous avez saisi toutes vos réponses, vous aurez accès aux explications d'experts pour tous les choix possibles.

5. Les participants peuvent réclamer un maximum de quatre heures de DPC pour un total de 12 crédits sous la Section 3 du programme de DPC du Collège royal des médecins et chirurgiens du Canada.

\section{Supported in part by the Department of Anesthesia, University of Toronto.}

Financé en partie par le département d'anesthésie, Université de Toronto.

Conflicts of interest None declared.

Conflit d'intérêt Aucun.

\section{References}

1. Canadian Institute for Health Information, Public Health Agency of Canada. Obesity in Canada: a joint report from the Public Health Agency of Canada and the Canadian Institute for Health Information. [Ottawa]: Public Health Agency of Canada; 2011. Available from URL: http://www.phac-aspc.gc.ca/hp-ps/hl-mvs/ oic-oac/index-eng.php (accessed April 18, 2013) [Institut canadien d'information sur la santé, Agence de la santé publique du Canada. Obésité au Canada: rapport conjoint de l'Agence de la santé publique du Canada et de l'Institut canadien d'information sur la santé. [Ottawa]: Agence de la santé publique du Canada; 2011. Disponible à l'adresse: http://www.phac-aspc.gc.ca/hp-ps/ hl-mvs/oic-oac/index-fra.php (consulté en anglais le 18 avril 2013)].

2. Cullen A, Ferguson A. Perioperative management of the severely obese patient: a selective pathophysiological review. Can J Anesth 2012; 59: 974-96.

3. Horner RL, Mohiaddin RH, Lowell DG, et al. Sites and sizes of fat deposits around the pharynx in obese patients with obstructive sleep apnoea and weight matched controls. Eur Respir J 1989; 2: 613-22.

4. Benumof JL. Obesity, sleep apnea, the airway and anesthesia. Curr Opin Anaesthesiol 2004; 17: 21-30.

5. Ahmad S, Nagle A, McCarthy RJ, Fitzgerald PC, Sullivan JT, Prystowsku J. Postoperative hypoxemia in morbidly obese patients with and without obstructive sleep apnea undergoing laparoscopic bariatric surgery. Anesth Analg 2008; 107: 138-43.

6. Littleton $S W$. Impact of obesity on respiratory function. Respirology 2012; 17: 43-9.

7. Pelosi P, Croci M, Ravagnan I, et al. The effects of body mass on lung volumes, respiratory mechanics, and gas exchange during general anesthesia. Anesth Analg 1998; 87: 654-60.

8. Cook TM, Woodall N, Frerk C; Fourth National Audit Project. Major complications of airway management in the UK: results of the Fourth National Audit Project of the Royal College of Anaesthetists and the Difficult Airway Society. Part 1: anaesthesia. Br J Anaesth 2011; 106: 617-31.

9. Cook TM, Woodall N, Harper J, Benger J; Fourth National Audit Project. Major complications of airway management in the UK: results of the Fourth National Audit Project of the Royal College of Anaesthetists and the Difficult Airway Society. Part 2: intensive care and emergency departments. Br J Anaesth 2011; 106: $632-42$

10. Langeron $O$, Masso E, Huraux $C$, et al. Prediction of difficult mask ventilation. Anesthesiology 2000; 92: 1229-36.

11. Kheterpal $S$, Han $R$, Tremper KK, et al. Incidence and predictors of difficult and impossible mask ventilation. Anesthesiology 2006; 105: 885-91.

12. Kheterpal S, Martin L, Shanks AM, Tremper KK. Prediction and outcomes of impossible mask ventilation: a review of 50,000 anesthetics. Anesthesiology 2009; 110: 891-7.

13. Ramachandran SK, Mathis MR, Tremper KK, Shanks AM, Kheterpal S. Predictors and clinical outcomes from failed Laryngeal Mask Airway Unique ${ }^{\mathrm{TM}}$ : a study of 15,795 patients. Anesthesiology 2012; 116: 1217-26.

14. Keller C, Brimacombe J, Kleinsasser A, Brimacombe L. The Laryngeal Mask Airway ProSeal(TM) as a temporary ventilatory device in grossly and morbidly obese patients before laryngoscopeguided tracheal intubation. Anesth Analg 2002; 94: 737-40.

15. Abdi W, Dhonneur $G$, Amathieu $R$, et al. LMA supreme versus facemask ventilation performed by novices: a comparative study in morbidly obese patients showing difficult ventilation predictors. Obes Surg 2009; 19: 1624-30.

16. Wong DT, Yang JJ, Jagannathan N. Brief review: The LMA Supreme $^{\mathrm{TM}}$ supraglottic airway. Can J Anesth 2012; 59: 483-93.

17. Juvin P, Lavaut E, Dupont H, et al. Difficult tracheal intubation is more common in obese than in lean patients. Anesth Analg 2003; 97: 595-600.

18. Fox WT, Harris $S$, Kennedy NJ. Prevalence of difficult intubation in a bariatric population, using the beach chair position. Anaesthesia 2008; 63: 1339-42.

19. Lundstrom LH, Moller AM, Rosenstock C, Astrup G, Wetterslev J. High body mass index is a weak predictor for difficult and failed tracheal intubation: a cohort study of 91,332 consecutive patients scheduled for direct laryngoscopy registered in the Danish Anesthesia Database. Anesthesiology 2009; 110: 266-74.

20. Ezri T, Medalion B, Weisenberg M, Szmuk P, Warters RD, Charuzi $I$. Increased body mass index per se is not a predictor of difficult laryngoscopy. Can J Anesth 2003; 50: 179-83.

21. Ezri T, Gewurtz G, Sessler DI, et al. Prediction of difficult laryngoscopy in obese patients by ultrasound quantification of anterior neck soft tissue. Anaesthesia 2003; 58: 1111-4.

22. Komatsu $R$, Sengupta $P$, Wadhwa A, et al. Ultrasound quantification of anterior soft tissue thickness fails to predict difficult laryngoscopy in obese patients. Anaesth Intensive Care 2007; 35: 32-7.

23. Rao SL, Kunselman AR, Schuler HG, DesHarnais $S$. Laryngoscopy and tracheal intubation in the head-elevated position in obese patients: a randomized, controlled, equivalence trial. Anesth Analg 2008; 107: 1912-8

24. Gonzalez H, Minville V, Delanoue K, Mazerolles M, Concina D, Fourcade $O$. The importance of increased neck circumference to intubation difficulties in obese patients. Anesth Analg 2008; 106: 1132-6.

25. Brodsky JB, Lemmens HJ, Brock-Utne JG, Vierra M, Saidman $L J$. Morbid obesity and tracheal intubation. Anesth Analg 2002; 94: 732-6.

26. Aslani A, Ng SC, Hurley M, McCarthy KF, McNicholas M, McCaul CL. Accuracy of identification of the cricothyroid membrane in female subjects using palpation: an observational study. Anesth Analg 2012; 114: 987-92.

27. Dinsmore J, Heard AM, Green RJ. The use of ultrasound to guide time-critical cannula tracheotomy when anterior neck airway anatomy is unidentifiable. Eur J Anaesthesiol 2011; 28: 506-10.

28. Nicholls SE, Sweeney TW, Ferre RM, Strout TD. Bedside sonography by emergency physicians for the rapid identification 
of landmarks relevant to cricothyrotomy. Am J Emerg Med 2008; 26: 852-6.

29. Dixon BJ, Dixon JB, Carden JR, et al. Preoxygenation is more effective in the 25 degrees head-up position than in the supine position in severely obese patients: a randomized controlled study. Anesthesiology 2005; 102: 1110-5; discussion 5A.

30. Boyce JR, Ness T, Castroman P, Gleysteen JJ. A preliminary study of the optimal anesthesia positioning for the morbidly obese patient. Obes Surg 2003; 13: 4-9.

31. Levitan RM, Mechem CC, Ochroch EA, Shofer FS, Hollander JE. Head-elevated laryngoscopy position: improving laryngeal exposure during laryngoscopy by increasing head elevation. Ann Emerg Med 2003; 41: 322-30.

32. Berthoud MC, Peacock JE, Reilly CS. Effectiveness of preoxygenation in morbidly obese patients. Br J Anaesth 1991; 67: 464-6.

33. Tanoubi I, Drolet P, Donati F. Optimizing preoxygenation in adults. Can J Anesth 2009; 56: 449-66.

34. Benumof JL. Preoxygenation: best method for both efficacy and efficiency. Anesthesiology 1999; 91: 603-5.

35. Baraka AS, Taha SK, Siddik-Sayyid SM, et al. Supplementation of pre-oxygenation in morbidly obese patients using nasopharyngeal oxygen insufflation. Anaesthesia 2007; 62: 769-73.

36. Coussa M, Proietti S, Schnyder P, et al. Prevention of atelectasis formation during the induction of general anesthesia in morbidly obese patients. Anesth Analg 2004; 98: 1491-5.

37. Gander S, Frascarolo P, Suter M, Spahn DR, Magnusson L. Positive end-expiratory pressure during induction of general anesthesia increases duration of nonhypoxic apnea in morbidly obese patients. Anesth Analg 2005; 100: 580-4

38. Delay JM, Sebbane M, Jung B, et al. The effectiveness of noninvasive positive pressure ventilation to enhance preoxygenation in morbidly obese patients: a randomized controlled study. Anesth Analg 2008; 107: 1707-13.

39. American Society of Anesthesiologists Task Force on Management of the Difficult Airway. Practice guidelines for management of the difficult airway: an updated report by the American Society of Anesthesiologists Task Force on Management of the Difficult Airway. Anesthesiology 2003; 98: 1269-77.

40. Henderson JJ, Popat MT, Latto IP, Pearce AC; Difficult Airway Society. Difficult Airway Society guidelines for management of the unanticipated difficult intubation. Anaesthesia 2004; 59: 675-94.

41. Dhonneur G, Abdi W, Ndoko SK, et al. Video-assisted versus conventional tracheal intubation in morbidly obese patients. Obes Surg 2009; 19: 1096-101.

42. Andersen LH, Rovsing L, Olsen KS. GlideScope videolaryngoscope vs. Macintosh direct laryngoscope for intubation of morbidly obese patients: a randomized trial. Acta Anaesthesiol Scand 2011; 55: 1090-7.

43. Wong DT, Yang JJ, Mak HY, Jagannathan N. Use of intubation introducers through a supraglottic airway to facilitate tracheal intubation: a brief review. Can J Anesth 2012; 59: 704-15.

44. Cook TM, Seller C, Gupta K, Thornton M, O'Sullivan E. Nonconventional uses of the Aintree Intubating Catheter in management of the difficult airway. Anaesthesia 2007; 62: 169-74.
45. Berkow LC, Schwartz JM, Kan K, Corridore M, Heitmiller ES. Use of the Laryngeal Mask Airway-Aintree Intubating Catheterfiberoptic bronchoscope technique for difficult intubation. J Clin Anesth 2011; 23: 534-9.

46. Combes $X$, Sauvat S, Leroux B, et al. Intubating laryngeal mask airway in morbidly obese and lean patients: a comparative study. Anesthesiology 2005; 102: 1106-9; discussion 5A.

47. Moore AR, Schricker T, Court O. Awake videolaryngoscopyassisted tracheal intubation of the morbidly obese. Anaesthesia 2012; 67: 232-5

48. Andersson LE, Baath M, Thorne A, Aspelin P, OdebergWernerman $S$. Effect of carbon dioxide pneumoperitoneum on development of atelectasis during anesthesia, examined by spiral computed tomography. Anesthesiology 2005; 102: 293-9.

49. Brodsky JB. Positioning the morbidly obese patient for anesthesia. Obes Surg 2002; 12: 751-8.

50. Reinius H, Jonsson L, Gustafsson $S$, et al. Prevention of atelectasis in morbidly obese patients during general anesthesia and paralysis: a computerized tomography study. Anesthesiology 2009; 111: 979-87.

51. Talab HF, Zabani IA, Abdelrahman HS, et al. Intraoperative ventilatory strategies for prevention of pulmonary atelectasis in obese patients undergoing laparoscopic bariatric surgery. Anesth Analg 2009; 109: 1511-6.

52. Almarakbi WA, Fawzi HM, Alhashemi JA. Effects of four intraoperative ventilatory strategies on respiratory compliance and gas exchange during laparoscopic gastric banding in obese patients. Br J Anaesth 2009; 102: 862-8.

53. Leme Silva $P$, Pelosi $P$, Rocco $P R$. Mechanical ventilation in obese patients. Minerva Anestesiol 2012; 78: 1136-45.

54. Peterson GN, Domino KB, Caplan RA, Posner KL, Lee LA, Cheney $F W$. Management of the difficult airway: a closed claims analysis. Anesthesiology 2005; 103: 33-9.

55. Membership of the Difficult Airway Society Extubation Guidelines Group: Popat M, Mitchell V, Dravid R, Patel A, Schampillai $C$, Higgs A. Difficult Airway Society Guidelines for the management of tracheal extubation. Anaesthesia 2012; 67: 318-40.

56. Eichenberger A, Proietti S, Wicky S, et al. Morbid obesity and postoperative pulmonary atelectasis: an underestimated problem. Anesth Analg 2002; 95: 1788-92.

57. Wong DT, Adly E, Ip HY, Thapar S, Maxted GR, Chung FF. A comparison between the Boussignac ${ }^{\mathrm{TM}}$ continuous positive airway pressure mask and the venturi mask in terms of improvement in the $\mathrm{PaO} 2 / \mathrm{F}(\mathrm{I}) \mathrm{O} 2$ ratio in morbidly obese patients undergoing bariatric surgery: a randomized controlled trial. Can J Anesth 2011; 58: 532-9.

58. Neligan PJ, Malhotra G, Fraser M, et al. Continuous positive airway pressure via the Boussignac system immediately after extubation improves lung function in morbidly obese patients with obstructive sleep apnea undergoing laparoscopic bariatric surgery. Anesthesiology 2009; 110: 878-84.

59. Zoremba M, Dette F, Gerlach L, Wolf $U$, Wulf $H$. Short-term respiratory physical therapy treatment in the PACU and influence on postoperative lung function in obese adults. Obes Surg 2009; 19: $1346-54$ 